\title{
PENINGKATAN KESADARAN MASYARAKAT RT 22 KELURAHAN PAHLAWAN PALEMBANG TENTANG PENCEGAHAN COVID-19 BERBASIS KELUARGA DENGAN MENERAPKAN 5M
}

\author{
Dewi Rury Arindari ${ }^{1}$, Dessy Suswitha ${ }^{2}$, Shinta Maharani ${ }^{3}$, Lela Aini ${ }^{4}$ \\ 1,2,3,4 STIK Siti Khadijah Palembang
}

Email Korespondensi: dessysuswitha13@gmail.com

Disubmit: 30 September 2021 Diterima: 04 Desember $2021 \quad$ Diterbitkan: 01 Januari 2022 DOI: https://doi.org/10.33024/jkpm.v1i1.5217

\begin{abstract}
ABSTRAK
Covid-19 merupakan penyakit yang penyebabnya adalah virus corona yang menyerang sistem pernapasan. Pemerintah sudah menghimbau masyarakatnya dengan memberikan protokol kesehatan untuk menghindari penularan wabah COVID-19, untuk dapat menerapkannya dibutuhkan kesadaran masyarakat. Salah satu hal yang bisa dilakukan untuk meningkatkan kesadaran masyarakat adalah dengan memberikan penyuluhan tentang Pencegahan COVID-19 berbasis Keluarga dengan Menerapkan 5M. Tujuan Pengabdian adalah untuk Meningkatkan Kesadaran Masyarakat RT 22 Kelurahan Pahlawan Palembang tentang Pencegahan COVID-19 berbasis Keluarga dengan Menerapkan 5M dapat terlaksana dengan baik. Metode yang digunakan dalam kegiatan pengabdian masyarakat adalah berbentuk pendidikan kesehatan dengan metode ceramah dan demontrasi. Kesimpulan adanya peningkatan kesadaran masyarakat berbasis keluarga di RT 22 kelurahan Pahlawan Palembang dalam menerapkan protokol Kesehatan 5M. Disarankan bagi peneliti selanjutnya agar dapat mengimplementasikan dan memberikan informasi terbaru tentang pencegahan virus Covid 19 selain penerapan $5 \mathrm{M}$ pada masyarakat yang lebih luas.
\end{abstract}

Kata Kunci: Peningkatan Kesadaran Masyarakat, Menerapkan 5M, Pencegahan Covid 19

\begin{abstract}
Covid-19 is a disease caused by a corona virus that attacks the respiratory system. The government has appealed to the public by providing health protocols to avoid the transmission of the COVID-19 outbreak, to be able to implement it, public awareness is needed. One of the things that can be done to increase public awareness is to provide counseling about Family-based COVID-19 Prevention by Implementing $5 \mathrm{M}$. The purpose of this service is to increase public awareness of RT 22 Pahlawan Palembang Village regarding Family-based COVID-19 Prevention by Implementing $5 \mathrm{M}$ can be carried out properly. The method used in community service activities is in the form of health education with lecture and demonstration methods. The conclusion is that there is an increase in familybased community awareness in RT 22, Pahlawan Palembang village in implementing the $5 \mathrm{M}$ Health protocol. It is recommended for further researchers to be able to implement and provide the latest information about the prevention of the Covid 19 virus in addition to the application of $5 \mathrm{M}$ to the wider community.
\end{abstract}

Keywords: Increasing Public Awareness, Implementing 5M, Prevention of Covid 19 


\section{PENDAHULUAN}

Covid-19 merupakan penyakit yang penyebarannya melalui virus corona yang menyerang sistem pernapasan tubuh. Tanda dan gejala umum virus COVID19 beberapa di antaranya, gangguan pernapasan akut seperti demam, batuk, kesulitan bernafas dan sesak napas, dimana Masa inkubasi rata-rata selama 5-6 hari dan 14 hari adalah masa inkubasi terpanjang (Yuliana, 2020).

WHO menyatakan sebanyak 213 negara sudah melaporkan ditemukannya kasus Covid-19 di Negara mereka. Data tercatat sebanyak 4.417.903 kasus dengan 297.382 kematian dan tingkat pertumbuhan kasus baru sebesar $7 \%$ per hari di seluruh dunia (WHO, 2020).

Pemerintah telah memberikan informasi kepada masyarakat dan keluarga dengan memberikan protokol kesehatan untuk menghindari penularan wabah COVID-19 dengan Menerapkan 5M, yaitu Mencuci tangan dengan air yang mengalir, mengurangi kebiasaan memegang hidung, mulut, mata, serta wajah. Rajin menggunakan Hand Sanitizer/cairan pembersih tangan lainnya jika tidak ada air di sekitar, memakai masker bila keluar rumah dan berada di tempat umum, menjaga jarak/ menghindari keramaian, mengurangi mobilitas dan menerapkan perilaku hidup bersih dan sehat sedari dini (Kemenkes RI, 2021)

Untuk mengurangi dan menghindari penyebaran wabah virus yang semakin luas, maka diperlukan kebijakan Pemerintah yang sudah ditetapkan dalam menghadapi pandemik wabah COVID-19 ini, tetapi diperlukan juga dukungan berbagai lapisan masyarakat dalam mengambil peran juga. Peran yang dibutuhkan adalah dengan menjalankan protokol Kesehatan yang sudah dibuat pemerintah. Untuk menjalankannya dibutuhkan kesadaran masyarakat. Salah satu hal yang bisa dilakukan untuk meningkatkan kesadaran masyarakat adalah dengan memberikan Pendidikan kesehatan tentang Pencegahan COVID-19 berbasis Keluarga dengan Menerapkan 5M (Syafrida, 2020)

Hasil studi yang telah dilakukan oleh Gina Aulia, et al (2021) tentang Edukasi Pencegahan Covid-19 Dengan Protokol Kesehatan 5M Dan Pentingnya Multivitamin Di Masa Pandemi Covid-19 yang menyatakan bahwa sebagian masyarakat telah melakukan upaya pencegahan dengan memakai masker menerapkan $5 \mathrm{M}$, pentingnya multivitamin di masa pandemic Covid-19. Hal ini sesuai dengan hasil pengabdian masyarakat dari Ani Meryati, et al (2021) tentang Meningkatkan Kesadaran Masyarakat Mengenai Pentingnya Menerapkan Protokol Kesehatan Sebagai Upaya Memutus Mata Rantai Penyebaran Covid-19 Di Kelurahan Ciputat dengan hasil sebagian masyarakat sudah menerapkan protokol kesehatan baik mengenai cara mencuci tangan dan menggunakan masker yang benar maupun jaga jarak aman agar terhindar dari penularan covid-19.

Salah satu upaya agar terhindar dari virus Covid 19 yang dapat di berikan kepada masyarakat dengan cara melakukan Penerapan $5 \mathrm{M}$ yang pada dasarnya merupakan semua perilaku kesehatan yang dilakukan atas kesadaran pribadi sehingga keluarga dan seluruh anggotanya mampu menolong diri sendiri pada bidang kesehatan serta memiliki peran aktif dalam aktivitas masyarakat. Dengan adanya deteksi dini, maka upaya pencegahan dapat dilakukan dengan cara rajin mencuci tangan, menggunakan handsanitizer, memakai masker pada saat keluar rumah, menjaga jarak, mengurangi mobilitas dan menerpakan perilaku hidup bersih dan sehat. Berdasarkan analisis kajian situasi maka perlunya dilakukan kegaiatan pengabdian kepada masyarakat di RT 22 Kelurahan Pahlawan Palembang tentang Pencegahan COVID-19 berbasis Keluarga dengan Menerapkan $5 \mathrm{M}$. 


\section{MASALAH}

Dengan semakin meningkatnya penyebaran Covid -19 yang belakangan ini menimbulkan keresahan seluruh lapisan masyarakat. Yang dapat menjadi permasalahan penting dalam program pengendalian dan pencegahan wabah Covid-19 di RT 22 Kelurahan Pahlawan Palembang pada khususnya. Kurangnya kesadaran dan pengetahuan serta pemahaman masyarakat dalam menerapkan protocol kesehatan. Upaya pencegahan yang dapat dilakukan adalah dengan kegiatan Pendidikan Kesehatan untuk meningkatkan pengetahuan dan kesadaran masyarakat RT 22 Kelurahan Pahlawan Palembang agar dapat tetap disiplin dalam menerapkan protokol Kesehatan.

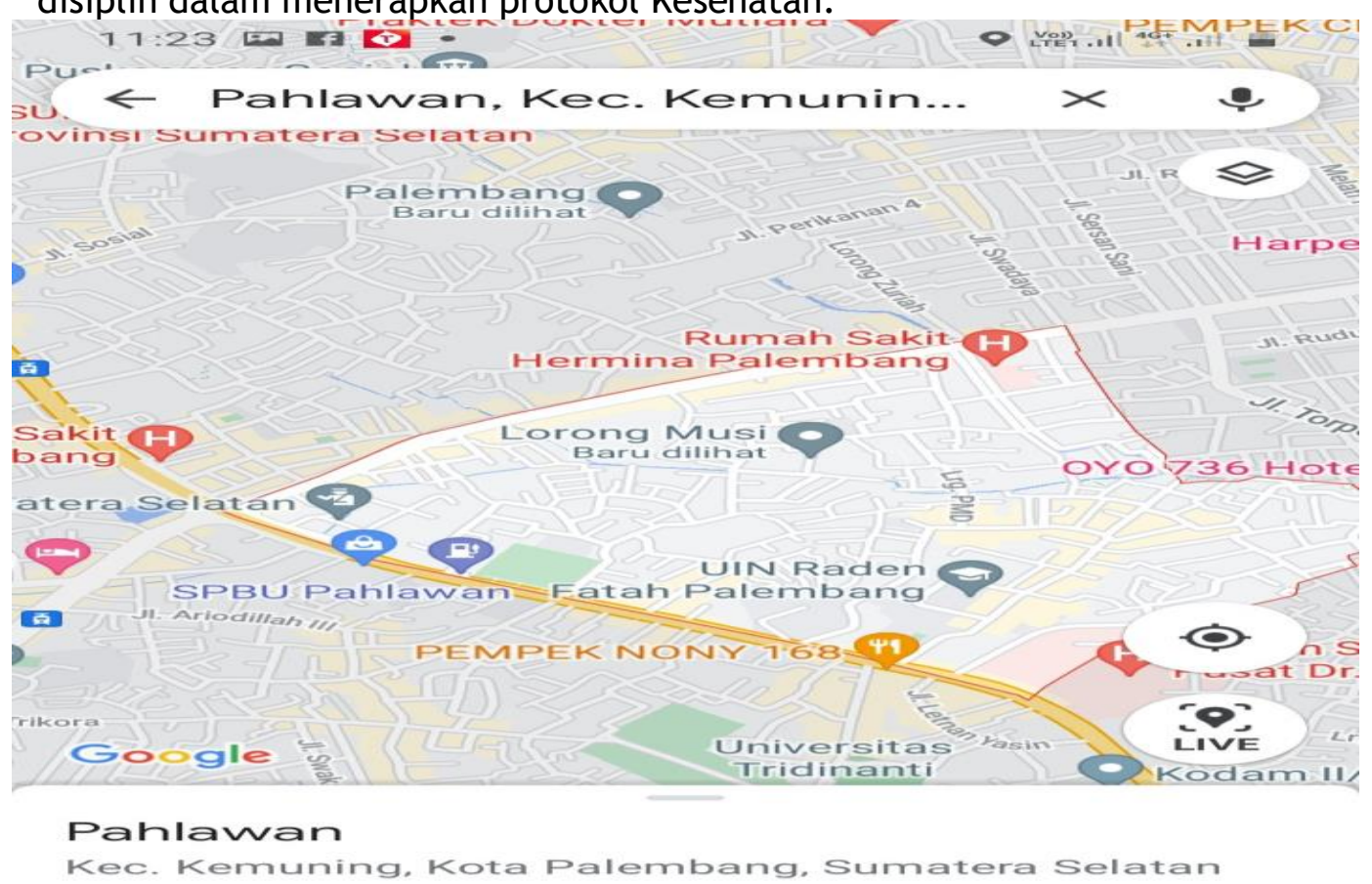

Gambar. 2.1. Lokasi Kegiatan Pengabdian kepada Masyarakat

\section{METODE}

Sasaran Kegiatan adalah semua Masyarakat Di RT 22 Kelurahan Pahlawan Palembang sebanyak 21 orang. Metode kegiatan ini berbentuk penyuluhan kesehatan dengan metode ceramah dan demontrasi serta pembagian Hansanitizer dan masker. Tahapan Kegiatan Pengabdian masyarakat yaitu sebagai berikut :

a. Tahap Perencanaan

Tahapan awal dengan penyusunan rencana yang dilakukan dengan cara windshield survey di dapatkan sebagian masyarakat yang tidak memakai masker dan tidak menjaga jarak serta tidak menerpakan protokol kesehatan, lokasi yang digunakan untuk kegiatan pengabdian ini yaitu halaman rumah ketua RT 22 Kelurahan Pahlawan Palembang. Setelah didapatkan data tersebut dilakukan kegiatan Tahap Persiapan.

b. Tahap Persiapan

Dilakukan penyiapan organisasi pelaksanaan dan penyiapan lapangan. Pada tahap persiapan pelaksana, tim mempersiapkan tenaga pelaksana dan pendukung yang dapat dilakukan oleh bagian dari masyarakat itu sendiri. Selanjutnya, pada tahap persiapan lapangan, diawali dengan melakukan studi kelayakan terhadap kelurahan yang akan dijadikan sasaran dilakukan 
secara formal ataupun informal. Serta target masyarakat yang ikut berpartisipasi.

c. Tahap Pelaksanaan

Merupakan salah satu tahap paling penting dalam proses pengabdian kepada masyarakat. Peran ketua RT maupun masyarakat sebagai sasaran program diharapkan dapat menjaga keberlangsungnya kegiatan yang telah dikembangkan. Pada tahap ini disampaikan dalam bentuk Pendidikan Kesehatan, demontrasi cara mencuci tangan, pembagian Masker, pembagian handsanitizer bagi masyarakat yang mengabaikan protocol Kesehatan.

d. Tahap Evaluasi

Tahap Evaluasi sebagai proses pengawasan dari pelaksana terhadap program pengabdian kepada masyarakat yang sedang berjalan dilakukan dengan melibatkan masyarakat. Evaluasi dilaksanakan dengan mengobservasi dan menilai respon Kemampuan Masyarakat dan keluarga dilihat pada saat di berikan evaluasi pertanyaan tentang pencegahan penyebaran Covid-19 Sebagian masyarakat masih kurang memahami dan mengabaikan protocol Kesehatan.

\section{HASIL DAN PEMBAHASAN}

Berdasarkan dari hasil pengabdian kepada masyarakat yang di berikan melalui Pendidikan Kesehatan secara langsung didapatkan Sebagian masyarakat sudah mengetahui tentang cara pencegahan penyakit Covid-19 dengan memakai masker dan menjaga jarak. Hal ini sesuai dengan hasil pengabdian masyarakat dari Gina Aulia, et al (2021) tentang Edukasi Pencegahan Covid-19 Dengan Protokol Kesehatan 5M Dan Pentingnya Multivitamin Di Masa Pandemi Covid-19 yang menyatakan bahwa sebagian masyarakat telah melakukan upaya pencegahan dengan memakai masker menerapkan $5 \mathrm{M}$, pentingnya multivitamin di masa pandemic Covid-19.

Kegiatan ini dilaksanakan satu hari yaitu pada Sabtu, 20 Maret 2021 dari pukul 10.00 - 11.00 WIB. Peserta kegiatan yaitu semua Masyarakat RT 22 Kelurahan Pahlawan Palembang. Media yang dipakai berupa leaflet, spanduk, dengan pemeriksaan kesehatan, pada akhir kegiatan Pendidikan Kesehatan di lakukan evaluasi kegiatan dengan memberikan beberapa pertanyaan kepada masyarakat, didapatkan Sebagian masyarakat mengerti dan memahami cara pencegahan penyebaran penyakit Covid -19 .

Program pengabdian masyarakat di RT 22 Kelurahan Pahlawan Palembang dapat diselenggarakan dengan baik dan berjalan dengan lancar sesuai dengan rencana kegiatan yang telah disusun dengan adanya Kerjasama dengan mahasiswa, kelurahan, ketua RT, dan masyarakat. Beberapa masyarakat belum mengerti cara pencegahan penyebaran penyakit Covid -19. Kegiatan ini mendapat sambutan sangat baik terbukti dengan keikutsertaan masyarakat dalam kegiatan Pendidikan Kesehatan. Selain itu dilakukan Program ini mampu memberikan pengetahuan dasar tentang Peningkatan Kesadaran Masyarakat dalam menerapkan protocol Kesehatan dengan 5M. Program ini dijalankan dengan maksud memberikan proteksi tambahan kepada masyarakat agar terhindar dari penyakit Covid-19. 


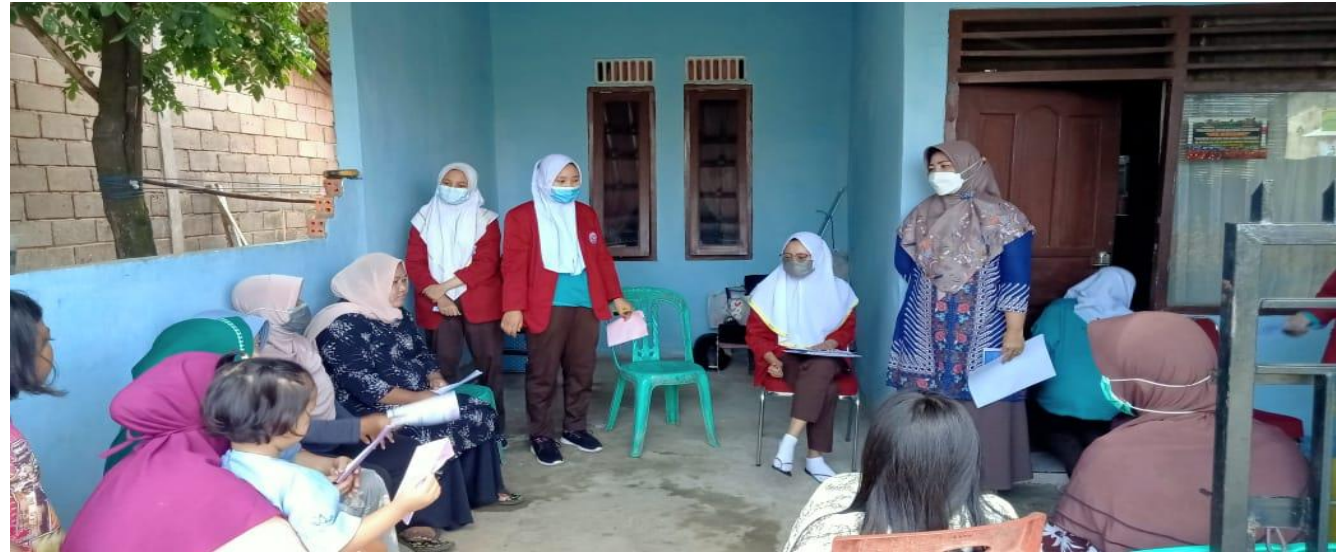

Gambar 4.1. Tahap Pelaksanaan pemberian Pendidikan Kesehatan dan Pemberian Leaflet
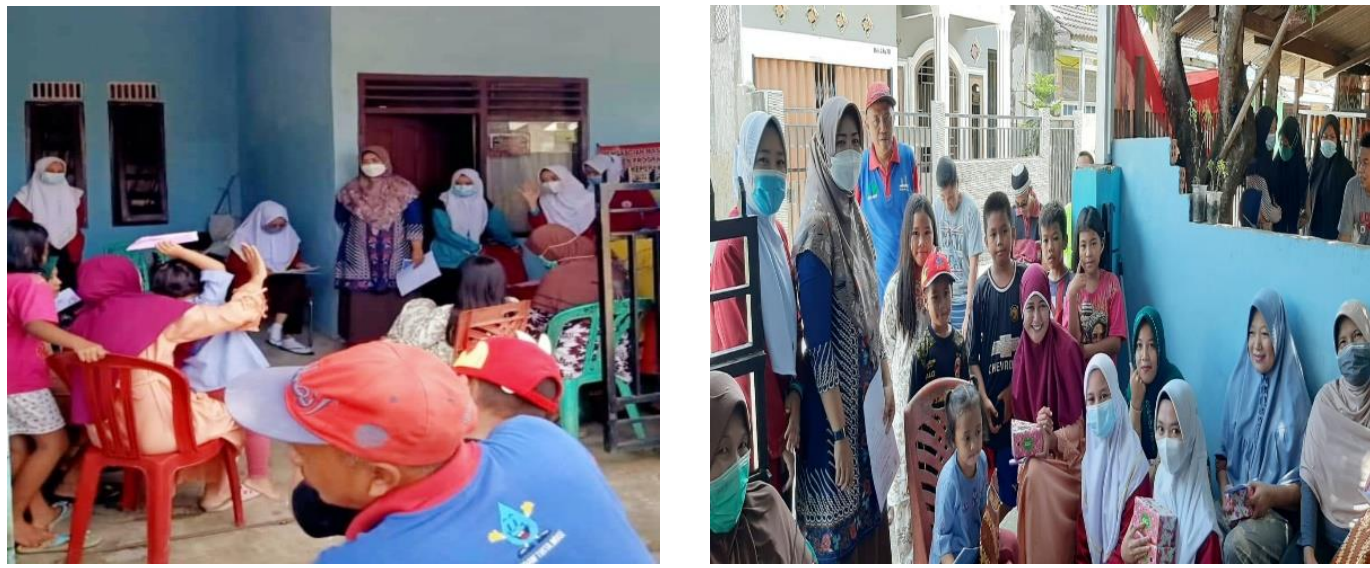

Gambar 4.2 Tahap Evaluasi memberikan pertanyaan kepada warga

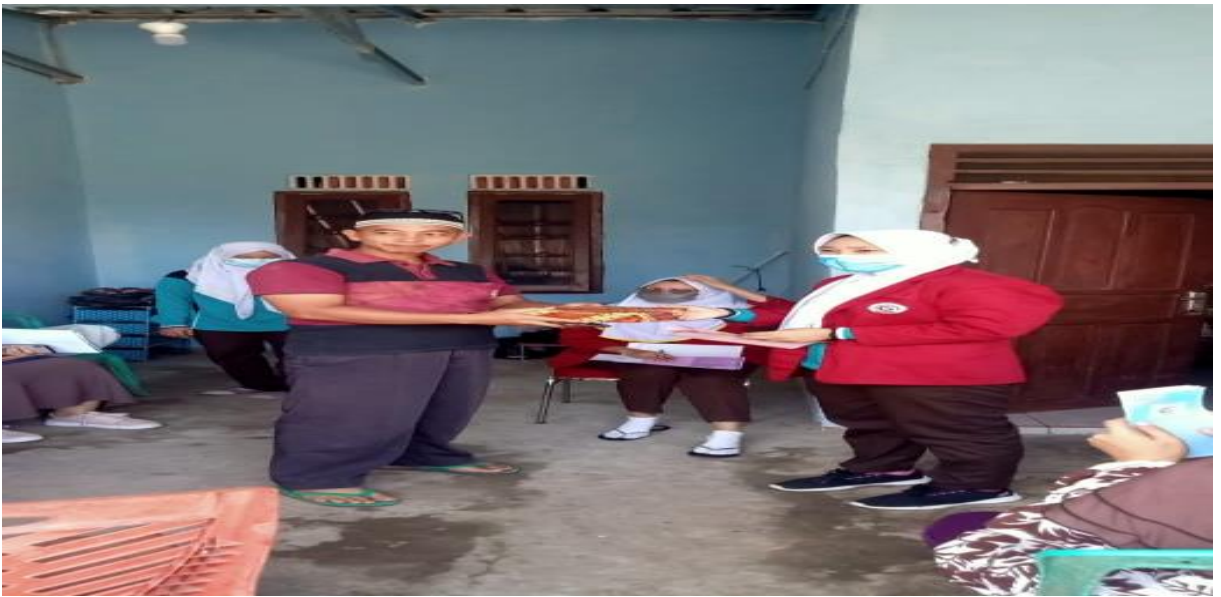

Gambar 4.3 Pemberian Doorprice bagi masyarakat yang dapat menjawab pertanyaan.

\section{KESIMPULAN}

Berdasarkan hasil kegiatan pengabdian kepada masyarakat yang telah dilakukan dapat diselenggarakan dengan baik dan berjalan dengan lancar sesuai dengan rencana kegiatan yang telah disusun, maka dapat di simpulkan Kegiatan ini berhasil dengan mendapatkan sambutan sangat baik terbukti dengan keikutsertaan masyarakat dalam kegiatan Pendidikan kesehatan dan meningkatnya Kesadaran Masyarakat dalam Pencegahan COVID-19 berbasis 
Keluarga dengan memakai masker, mengetahui cara mencuci tangan dengan benar, menjaga jarak, menguragi mobilitas di luar rumah dan menerapkan perilaku hidup bersih dan sehat.

\section{DAFTAR PUSTAKA}

Ani Meryati, et al. (2021). Meningkatkan Kesadaran Masyarakat Mengenai Pentingnya Menerapkan Protokol Kesehatan Sebagai Upaya Memutus Mata Rantai Penyebaran Covid-19 Di Kelurahan Ciputat. DEDIKASI PKM UNPAM Vol. 2, No. 2, Mei, 2021, Hal (169-174)

Gina Aulia, et al. (2021). Edukasi Pencegahan Covid-19 Dengan Protokol Kesehatan 5M Dan Pentingnya Multivitamin Di Masa Pandemi Covid-19. JAM: Jurnal Abdi Masyarakat Vol. 2, No.1, Mei 2021, Hal. 133-139

Kemenkes RI. Pedoman dan Pencegahan Pengendalian Coronavirus Disease (COVID19). Jakarta : Kementerian Kesehatan RI; 2020.

Kemenkes RI. (2021). 5 M Dimasa Pandemi COVID-19 di Indonesia. URL: http://www.padk.kemkes.go.id/ article/read/2021/02/01/46/5mdimasa-pandemi-covid-19-diindonesia.html. Diakses tanggal 8 September 2021.

Risidah Ainur, et al. (2020). Meningkatkan keasadaran Masyarakat Terhadap Pencegahan Covid-19 Melalui Video Edukasi Penerapan Protokol Kesehatan.Jurnal IlmiahPengabdian kepada Masyarakat Logista Vol 4 No 2 tahun 2020, Hal 414-419

Syafrida, S. (2020). Bersama Melawan Virus Covid 19 di Indonesia. SALAM: Jurnal Sosial Dan Budaya Syar-I, 7(6). https://doi.org/10.15408/sjsbs.v7i6.15325

World Health Organization (2020). Novel Coronavirus (2019-nCoV). Citroner, G. Healthline. (2020). China Coronavirus Outbreak: CDC Issues Warning, Multiple Cases in U.

Yatimah Durotul, et al. (2020). Peningkatan Kesadaran Masyarakat tentang Pencegahan Covid-19 berbasis Keluarga dengan memanfaatkan Motion Grafis di Jakarta Timur.Jurnal Karya Abdi Vol 4 No 1 Juni 2020, Hal 246-255

Yuliana. (2020). Corona virus diseases (COVID-19); Sebuah tinjauan literatur. Wellness and Healthy Magazine, 2(1), 187-192. https://doi.org/10.2307/j.ctvzxxb18.12 